\title{
He was not alone: Bosman in context
}

\author{
Dr Borja García
}

School of Sport, Exercise and Health Sciences, Loughborough University (UK)

Published in: A. Duval and B. Van Rompuy (eds.) (2016) The Legacy of Bosman, The Hague: TMC ASSER Press, pp. 13-30. ISBN: 978-94-625-120-3. DOI: 10.1007/978-94-625-120-3_2

Cite as follows:

García, Borja (2016) 'He was not alone: Bosman in context', in A. Duval and B. Van Rompuy (eds.) The Legacy of Bosman, The Hague: TMC ASSER Press, pp. 13-30. ISBN: 978-94-625-120-3. DOI: 10.1007/978-94-625-120-3_2

\section{(C) Dr Borja García 2016}

\begin{abstract}
This chapter analyses the social, political, historical and economic context of the Bosman case. The chapter argues that Bosman needs to be understood as yet another stage of a continued process of commercialisation and transformation in European football. Football players fought to transform their employment conditions since the 1960s. Clubs questioned the legitimacy of UEFA to regulate European football and organise club competitions as they wanted a larger share of the commercial profits of the game. Finally, political institutions in Brussels started to exert pressure on football governing bodies to modify the international transfer system. The chapter argues that, taking these into account, major transformations in the governance and regulation structures of football were needed, and they would have happened even without the Bosman ruling. Consequently, Bosman cannot be seen, on its own, as the only cause of the transformation of modern football in Europe. Finally, the chapter dedicates some space to Jean Marc Bosman's legal team composed by Luc Misson and Jean Louis Dupont. It was their legal expertise what made a challenge before the Belgian and European courts also possible.
\end{abstract}

Keywords: Bosman ruling; football; globalisation; nationality quotas; right to retain

\footnotetext{
* Senior Lecturer in Sport Policy and Management; School of Sport, Exercise and Health Sciences, Loughborough University. Leicestershire, LE11 3TU, United Kingdom; Email: b.garcia-garcia@lboro.ac.uk.
} 


\section{Introduction}

The main message of this chapter is to explain that Jean-Marc Bosman was not a lone ranger; his case was the culmination rather than the starting point of a process of change in European football. Bosman (on its own) did not destroy European club football either, as claimed by the then president of UEFA Lennart Johansson. ${ }^{1}$ Thus, this chapter provides the context to understand the circumstances under which Jean-Marc Bosman decided to take his contractual dispute to court. Only when looking at the case within its wider context, one can understand the consequences of the CJEU's ruling. It is not possible to grasp what has happened after the ruling without taking into account the socio-political and economic reality of European football in the late 1980s and early 1990s.

The chapter argues that Bosman ${ }^{2}$ should not be considered as the origin of what some have called recently 'modern football', ${ }^{3}$ but perhaps just as an accelerator of a process that was already in motion when, for example, the Premier League and the UEFA Champions League kicked-off in 1992 (three years before the ruling). Moreover, it is quite difficult to sustain that these changes would not have happened with a different decision of the Court in Bosman. If the Court would have found in favour of UEFA and the Belgian Football Association (FA), this may have slowed down the process of transformation of football; but given the development and globalisation of professional sport since $1995,{ }^{4}$ we would have gotten to the current point one way or another.

The chapter proceeds in four steps. First, it analyses the problems in the regulation of footballers' working conditions that led to conflicts between the players, on one side, and clubs and governing bodies, on the other. A long term perspective of those conflicts is necessary to understand why and how Jean-Marc Bosman took his case to the Belgian court. Second, the chapter reviews briefly the historical and economic development of football, with a special focus on the transformations from the 1970s. Here, the chapter addresses the economic context of European football, especially the liberalisation of the television market in the 1980s and 1990s. In the fourth section, the chapter enters into the political, legal and personal context of the Bosman case, analysing the role played by Luc Misson and Jean-

\footnotetext{
${ }^{1}$ Johansson, This Ruling Is Nothing Short of a Disaster, (The European, 21 December 1995).

${ }^{2}$ Case C-415/93 Jean Marc Bosman v. Union Royale Belge Sociétés de Football Association [1995] ECR I4921.

${ }^{3}$ See Giulianotti 1999, p 168 et seq.

${ }^{4}$ See for example Niemann, García and Grant 2011.
} 
Louis Dupont, the player's legal team. Finally, the chapter concludes with an overall analysis of the different elements that made a case and a ruling such as Bosman possible.

\section{The transfer system and nationality quotas: A governance problem}

The first section of the chapter analyses the regulation of footballer's working conditions that, at the end of the day, were the rules challenged by Bosman's legal team before the courts. However, here we have taken a non-legal point of view. In doing so, we invite the reader to consider the Bosman case well beyond its legal confines, particularly in relation to the balance of power among the stakeholders involved in the game.

Thus, if we adopt a governance perspective to the players market, the first point to note from the outset is that the control structures of football traditionally positioned players at the bottom of the football pyramid. ${ }^{5}$ This is a result of the way in which player registration works. Clubs must register their players with their respective national federation or league to participate in competitions. In turn, it is the responsibility of these governing bodies to regulate and decide which players can be registered to play in the competitions they organise. Football governing bodies have traditionally adopted two sets of norms to regulate the employment and registration of footballers: transfer systems and nationality quotas. ${ }^{6}$

\subsection{The transfer system}

The so-called transfer system is a set of rules that regulate the circumstances under which players can move from one club to another. Transfer systems were said to protect small clubs that dedicate their resources to train and educate young players, so that the richest clubs cannot just 'steal' the players once they had finished their grass-roots education. ${ }^{7}$

The origins of the transfer system can be traced back to the days when English football first turned professional. In the 1880s, the English Football League created a system of player registration that prevented players from changing clubs during the season. Moreover, the Football League rules required the player's club permission for any transfer to proceed at the end of the season, ${ }^{8}$ hence creating the 'retain and transfer principle'. ${ }^{9}$ The retain and transfer system did not change much until the 1960s. If anything, it made things even more difficult

\footnotetext{
${ }^{5}$ Tomlinson 1983, p 173.

${ }^{6}$ Lanfranchi and Taylor 2001, p 218.

${ }^{7}$ Roderick 2006, p 116.

${ }^{8}$ McArdle 2000, p 19.

${ }^{9}$ Roderick 2006, p 116.
} 
for players, as the system went global and was adopted by leagues and governing bodies world-wide. ${ }^{10}$ The foundation of FIFA 'led to the formalisation of the transfer system at the international level'. ${ }^{11}$ FIFA adopted a comprehensive set of regulations on international transfers in $1953 .{ }^{12}$ FIFA normally implemented its transfer regulations world-wide, but between 1979 and 1995 UEFA dealt with international transfers within its territory and operated an arbitration scheme in case of disputes. ${ }^{13}$ Following Bosman in 1995, FIFA decided to regain control over the implementation of the transfer system in UEFA's territory, thus being the sole authority for international transfers world-wide.

Challenges to the transfer system came, naturally, from the players. It first began at the national level, when footballers' unions protested against the regulations governing transfers between clubs within their own country. Perhaps unsurprisingly, the first challenges came from England. The English Professional Footballers’ Association (PFA) stepped up its fight to modify footballers' employment conditions in the early 1950s; the object of the PFA's attack was the retain and transfer system and the regulation of the maximum wage. ${ }^{14}$ The occasion came with Newcastle United's refusal to grant a transfer to George Eastham in December 1959, hence, making use of its right to retain the player. ${ }^{15}$ Eastham, with the support of the players union, decided to challenge in court the English transfer system, arguing it was in breach of restraint of trade regulations. ${ }^{16}$ The result of the proceedings was that the judgment found in favour of the player, as it considered that the retention elements of the transfer system went beyond what was necessary to ensure that clubs were able to protect their legitimate interests. ${ }^{17}$ Thus, Eastham precipitated the introduction of a new transfer system in England which addressed the concerns of the ruling, eventually dismantling the retain principle. It should be no surprise, then, that following Eastham the PFA continued its efforts to get better working conditions for the players. In 1961, the maximum wage ${ }^{18}$ was

\footnotetext{
${ }^{10}$ McArdle 2000, p 25.

${ }^{11}$ Lanfranchi and Taylor 2001, p 216.

12 Opinion of Advocate General Lenz, Case C-415/93 Union royale belge des sociétés de football association ASBL v Jean-Marc Bosman, Royal club liégeois SA v Jean-Marc Bosman and others [1995] ECR I-4930, para 20.

${ }^{13}$ UEFA (2005) Vision Europe, the direction and development of European football over the next decade, p 16.

${ }^{14}$ Greenfield and Osborn 2001, p 76.

${ }^{15}$ Ibid., p 79.

${ }^{16}$ Ibid., p 80.

${ }^{17}$ George Eastham v Newcastle United FC [1963] 3 All ER 139; See also Greenfield and Osborn 2001, pp 8081; McArdle 2000, pp 27-28.

${ }^{18}$ An agreement by the clubs and the governing body to limit the salary of the players (i.e. what we call nowadays a salary cap, but without the players' agreement).
} 
abolished. ${ }^{19}$ Platts and Smith point out that these developments cannot be understood in isolation, nor can they be disconnected from the wider social and economic development of English football and English society. ${ }^{20}$ A similar claim is made in this chapter, albeit for the wider European context, as we argue the need to understand Bosman as part of a process.

Therefore, the momentum that started in England with Eastham and the abolition of the maximum wage jumped over the channel to 'the continent'. In France, the footballers' trade union negotiated in 1969 with the French league the abolition of the 'life contract which had bound players to a club until the age of $35^{\prime} \cdot{ }^{21}$ The agreement stipulated that, at the end of a contract, players were free to sign with whichever employer they chose. The negotiations between the players, clubs and the French FA were not smooth and there were even suggestions in 1972 that the agreement needed to be reversed. This prompted French footballers to call for a strike. ${ }^{22}$ France was not the only country where players decided to fight for their working rights. In Spain, professional footballers challenged the so-called derecho de retención (right to retain) ${ }^{23}$ in the late 1970 s and early 1980s. The Spanish Footballers' Union (Asociación de Futbolistas Españoles, AFE in its Spanish acronym) called three strikes in the period between 1979 and 1982. The first two strikes, in 1979 and 1980, had a considerable impact bringing Spanish professional football to a halt. ${ }^{24}$ The third strike in 1982 led to the intervention of the national government to facilitate an agreement between clubs, the Spanish FA and the players. $^{25}$

In their struggle with clubs and the national FA, Spanish footballers achieved the abolition of the right to retain and a transformation of the transfer system and other employment conditions. ${ }^{26}$ Not only that, but in 1985, as part of these negotiations, the Spanish government

\footnotetext{
${ }^{19}$ Platts and Smith 2010, p 650.

${ }^{20}$ Ibid., p 645 et seq.

${ }^{21}$ Lanfranchi and Taylor 2001, p 217.

${ }^{22}$ UNFP 2008.

${ }^{23}$ The right to retain stipulated that clubs could retain the registration of players at the end of their contract by offering a 10 per cent salary rise. Players were unable to move to other clubs without the consent of their employer. See La retención en el fútbol español, práctica 'esclavista' hasta 1979 (El País, 29 March 1985). http://elpais.com/diario/1985/03/29/deportes/480898805_850215.html. Accessed 21 July 2015.

${ }^{24}$ González, Histórico: Se consumó la huelga de futbolistas (El País, 4 March 1979). http://elpais.com/diario/1979/03/04/deportes/289350006_850215.html. Accessed 21 July 2015; González, La asociación de futbolistas mantuvo la huelga, pero jugarán casi todos los profesionales (El País, 11 April 1982). http://elpais.com/diario/1982/04/11/deportes/387324003_850215.html. Accessed 21 July 2015.

${ }^{25}$ González, Los futbolistas desconvocaron oficialmente la huelga (El País, 13 April 1982). http://elpais.com/diario/1982/04/13/deportes/387496825_850215.html. Accessed 21 July 2015.

${ }^{26}$ La retención en el fútbol español, práctica 'esclavista' hasta 1979 (El País, 29 March 1985). http://elpais.com/diario/1985/03/29/deportes/480898805_850215.html. Accessed 21 July 2015; Paradinas, El derecho de retención de futbolistas, a punto de desaparecer (El País, 1 June 1979). http://elpais.com/diario/1979/06/01/deportes/297036015_850215.html. Accessed 21 July 2015, .
} 
adopted a decree (RD 1006/85), whereby professional sportspersons could terminate their contracts upon the payment of a proportionate compensation to their employer. ${ }^{27}$ Thus, it was a decade before Bosman that in Spain football players were granted similar rights to those that the Court recognised in 1995 to Jean-Marc Bosman. Again, this is a clear indication that the judgment of the CJEU in 1995 was by no means revolutionary.

There is no evidence available to establish a formal link between the different 'liberation' movements of football players in different countries, but there is clearly a pattern whereby footballers in the 1960s and 1970s challenged their situation at the bottom of the football pyramid as they mobilised to improve their conditions.

\subsection{Nationality quotas}

Nationality quotas are intended to fix the maximum number of non-national players that a club can field in any given game. Nationality quotas are normally justified as a means to ensure the quality of national teams and to maintain the identification of the supporters with their club. ${ }^{28}$ Although the concept of nationality quotas is relatively simple, it is difficult to trace the evolution of the implementation of quotas in European football. This is due to the variation among countries. ${ }^{29}$ Despite these asymmetries, quotas are based on a common principle; the differentiation between national and foreign players.

Whilst the transfer system was quickly institutionalised at the international level, nationality quotas remained a matter for national FAs for a long time, ${ }^{30}$ which contributed to a diversity of regulations in this area. ${ }^{31}$ For example, in Italy, the national FA permitted from 1947 the recruitment of five foreign players per club; however, it later banned all foreign players from 1966 to $1980 .^{32}$ Similarly, in Spain foreign players were allowed until 1962, when a total ban was introduced; in 1973 a quota of two per club was adopted. ${ }^{33}$ Thus, there was a wide diversity of nationality quotas in Europe with changes in regulation linked most of the time to the performances of the national teams in the World Cup or the European Championship.

\footnotetext{
${ }^{27}$ La retención en el fútbol español, práctica 'esclavista' hasta 1979 (El País, 29 March 1985). http://elpais.com/diario/1985/03/29/deportes/480898805_850215.html. Accessed 21 July 2015. ; See also García et al. 2011.

${ }^{28}$ Roderick 2006.

${ }^{29}$ Lanfranchi and Taylor 2001, pp 218-219.

${ }^{30}$ Ibid, pp 49-50.

${ }^{31}$ Greenfield and Osborn 2001, p 85.

${ }^{32}$ Lanfranchi and Taylor 2001, p 96.

33 Ibid., p 97.
} 
Nationality quotas, however, were not attacked by footballers' unions. Logically, national unions of footballers endorsed any regulation that protected their members from competition by foreign players. It is in this area of nationality quotas that Bosman arguably made a bigger impact. And perhaps in this respect the judgment was more ground-breaking and slightly more distanced from its wider context. One needs to be cautious with this line of reasoning though. Whereas the implications of Bosman for nationality quotas were perhaps stronger than for transfers, it is nevertheless possible to find traces of important contextual developments suggesting that the evolution of professional football was heading towards (at the very least) a relaxation of nationality quotas.

Nationality quotas found opposition, naturally, in those employers (clubs) willing to sign foreign players. Thus, in 1976 the CJEU issued a preliminary ruling in Donà, ${ }^{34}$ a case that originated in Italian football. In Donà the CJEU noted clearly that nationality quotas were contrary to European law. The Court pointed out that the prohibition of discrimination based on nationality does not apply only to the action of public authorities, but also to any rules aimed at regulating employment and services (i.e. rules adopted by football governing bodies and/or clubs). ${ }^{35}$

Donà could have been a severe blow for nationality quotas in club football, but in fact they remained in place for another 20 years. This was possible because the reaction of other EU institutions to the CJEU ruling was relatively conciliatory. This timid reaction helps to explain, perhaps, why Bosman was perceived as such a shock by European football stakeholders. ${ }^{36}$ In 1978, following negotiations with the European Commission, UEFA agreed that it would authorise clubs to hire as many foreign players as they wanted, but that they would be restricted to just fielding two such players in any game. ${ }^{37}$

The Commission engaged in further negotiations with UEFA again in 1984 when Commissioner Peter Sutherland requested the end of restrictions for EU players, but no progress was really made and nationality restrictions remained in place. ${ }^{38}$ This of course was changed abruptly by Bosman, which prompted UEFA and national FAs to abolish nationality quotas for EU players almost immediately after the ruling.

\footnotetext{
${ }^{34}$ Case C-13/76 Donà v. Mantero [1976] ECR 01333.

${ }^{35}$ Ibid., para 17; see also Case C-36/74 Walrave and Koch v. Association Union Cycliste Internationale [1974] ECR 01405, para 17.

${ }^{36}$ García 2007, p 205.

${ }^{37}$ European Commission (1996) Note de la DG4 présentée à la Commission: Conséquences de l'arret Bosman; affaire C 415/93 de la Court de Justice. SEC 212/1.; See also supra n 2, Bosman.

${ }^{38}$ Parrish 2003, p 91; Greenfield and Osborn 2001, p 85.
} 


\subsection{Low political visibility}

Up to this point, this chapter has explained how the regulation of the players market was heavily debated well before Bosman. By December 1995 the employment conditions of football players had been debated throughout Europe for more than twenty years. Bosman and its outcomes were not a surprise. It was a question of visibility rather than something completely new or unexpected. The reaction of the European Commission to Donà illustrates this point perfectly. The Commission's reaction indicates that football was not at that time a priority; otherwise, they would have been more assertive. Moreover, in the mid-1970s, football was not the major commercial industry that it is today. Challenges and protests to the transfer system and nationality quotas increased over time just as the commercialisation of the game developed thanks to the possibilities offered mainly by television. Therefore, it is almost impossible to separate the regulation of players' employment conditions to the historical and economic development of football as an industry in Europe.

\section{Football, from entertainment to industry}

This section briefly depicts the evolution of football from a mere leisure activity in British schools, where it was born, to the highly important economic industry that it has become. Specific attention is paid to the development of football after the Second World War and, more concretely, to the importance of television in shaping modern football.

The origins of football as a game are difficult to trace, for 'characters have been depicted kicking a ball in Egyptian relics, religious paintings, Grecian vases' and it even 'existed in ancient China and Japan, in the Americas before the Europeans arrived, and in most European countries long before it became officially recognised'. ${ }^{39}$ At the beginning of the nineteenth century football was played in public schools all around England, although the formats and rules of the game were very different from place to place: Rugby, Harrow, Shrewsbury all had their particular version of a game played between two teams and involving a ball. ${ }^{40}$ Football was well established in the English public schools by the middle of the nineteenth century, but none of the schools played against each other, and, as a result, the rules were numerous and inconsistent. ${ }^{41}$

\footnotetext{
${ }^{39}$ Murray 1994, p 1.

${ }^{40}$ Marples 1954, p 107.

${ }^{41}$ Murray 1994, p 13.
} 
Amidst different efforts to find a common format for the game, Ebenezer Cobb Morley called a meeting of representatives from clubs in the London area with the purpose of 'forming an association with the object of establishing a definite code of rules for the regulation of the game'. ${ }^{42}$ The meeting, held on 26 October 1863 at the Freemasons Tavern in London, was the foundation of the London Football Association. At that time the London FA was just one of many FAs around the country with the Sheffield FA being the main competitor. ${ }^{43}$ In 1877 both FAs reached a compromise agreement, with the London FA standing virtually as the sole authority of the game in England and being called simply 'the Football Association' without any location attached to it. By 1905 the Football Association had 10,000 members. ${ }^{44}$

The Football Association had no option but to recognise professional football in July $1885 .{ }^{45}$ In 1871 the Football Association introduced the Challenge $\mathrm{Cup}^{46}$ and in 1888 the first league competition (the Football League) was played. ${ }^{47}$ The 1880 s witnessed a surge in the popularity of football, closely linked to the social transformation brought about by the Industrial Revolution in England. It can be argued that, from that moment on, football has not ceased to grow as an economic activity, reaching the levels that made Bosman, the Premier League, the UEFA Champions League and even the Qatar 2022 World Cup possible. It is exactly for these reasons that one needs to understand this historical and economic evolution of football in order to grasp fully the importance of Bosman. The work of Richard Giulianotti is useful to explain football's development, as he provides a socio-cultural account that brings together the economic growth of the game with its impact on other social dimensions. Thus, Giulianotti divides football's development into three stages: ‘traditional', 'modern' and 'postmodern' ${ }^{48}$

The 'traditional' period lasted until after the First World War and it was marked by 'the establishment of the game's rules, their international diffusion and the formation of national associations to administer the sport under the aegis of ruling elites' ${ }^{49}$ The 'modern' era of football is sub-divided into three periods. 'Early modernity', running from the 1920 s to the Second World War. During that time the Olympic Games and the World Cup cemented

\footnotetext{
${ }^{42}$ Ibid., p 14.

${ }^{43}$ Ibid.

${ }^{44}$ Ibid., p 15.

${ }^{45}$ Giulianotti 1999, pp 4-5.

${ }^{46}$ Murray 1994, p 17.

${ }^{47}$ Giulianotti 1999, p 5

${ }^{48} \mathrm{Ibid}$

${ }^{49}$ Giulianotti 1999, p 166.
} 
football's global status. During this period football became the major national sport in Europe and Latin America, players started to emerge as national heroes and earn better than average wages, but they lacked long-term security. ${ }^{50}$ The 'intermediate modernity' of football lasted from the post war period to the early 1960s. In this period continental confederations (such as UEFA) emerged as another tier of governance for the game and, above all, television became more prevalent in family homes, making the skills of top players known world-wide. ${ }^{51}$ 'Late modernity' ran from the early 1960s to the late 1980s. Consumer culture and youth culture had a massive impact on the game, with players becoming superstars and icons of modernity (Manchester United's Northern Irish star George Best is one of the best examples); revenues from sponsorship and merchandising gradually started to overcome gate-receipts as the first source of income for clubs. ${ }^{52}$

\section{1. 'Post-modern' football}

This gets us to what Giulianotti in his sociological framework called football's 'post-modern' era which began in the late 1980s and has been evolving ever since. In general, many others (including academics, but especially football activists that proclaim to be 'against modern football ${ }^{53}$ ) have adopted the label of 'modern football' to designate this era of European and global football. Regardless of the semantic distinctions, the meaning behind the concepts is very similar. According to Giulianotti, post-modern football has entailed a major commercialisation of the sporting activity and the influence of television companies in controlling clubs and financing the game. ${ }^{54}$ Brand new or totally refurbished stadiums became a symbol of this new era of football, where television deals and ticket distribution policies maximise income, but may in turn damage the interests of the most dedicated supporters. ${ }^{55}$ In the 'post-modern' era fans represent a new middle class, 'a new kind of football spectator keen to produce and consume a variety of football media' ${ }^{56}$ With television revenues multiplying the benefits of top clubs, tournaments have become a huge

\footnotetext{
${ }^{50}$ Ibid., p 167.

${ }^{51}$ Ibid., p 168.

52 Ibid.

${ }^{53}$ See for example Cloake, Why Stand Against Modern Football? (NewStatesman, 23 August 2013),

http://www.newstatesman.com/business/2013/08/why-stand-against-modern-football. Accessed 22 July 2015;

The Stand Against Modern Football fanzine. http://www.standamf.com/. Accessed 1 September 2015.

${ }^{54}$ Ibid., p 168. See also Webber 2014.

${ }^{55}$ Giulianotti 1999, p 169.

56 Ibid.
} 
business and the elite players enjoy higher than ever wages, especially after the Bosman ruling. ${ }^{57}$

In his analysis, Giulianotti himself refers to Bosman, but it can be seen above that this is clearly embedded in an ongoing narrative of commercialisation and change of European football that started well before the Court delivered its verdict in December 1995. What Giulianotti points out, and it is recognised in this chapter as well, that Bosman was undoubtedly an accelerator that had important consequences, not least the increased wage levels for the top players in Europe. Another important point in Giulianotti's analysis is that the modernisation and commercialisation of European football has come hand in hand with the increase in the revenues from the selling of the game's broadcasting rights. The reality of modern (or post-modern) European football cannot be understood without mentioning the importance of television. This is another important piece in the Bosman jigsaw.

\subsection{From European Cup to Champions League: The arrival of 'sportainment'}

The Champions League is UEFA's top flight competition for football clubs. It is the current version of the European Champions Cup that was established in 1955. The European Champions Cup was born as a competition for the league champions of various European countries. FIFA, the world's football governing body, insisted at the time that the competition would be organised by UEFA; thus, the competition 'consolidated UEFA's role in European football as the sovereign organisation with regard to pan-European competitive structures' ${ }^{58}$

Arguably, the evolution of the European Cup is one of the best examples of the economic transformation of football analysed in the section above. The arrival of the Champions League when the Bosman case was already in the courts, but three years before the CJEU ruling, is yet another element to explain the Bosman case. It is perhaps also possible to consider that both the Champions League and Bosman are actually stages of the same process. So they are symptoms, rather than the cause, of European football's transformation. For this reason, any analysis of Bosman and its context would be incomplete without taking into account European club competitions.

The European Champions Cup was played in almost the same format from 1955 to 1991. In the late 1980s and early 1990s the concept of a European league (as compared to a knock-out

\footnotetext{
${ }^{57}$ Ibid.

${ }^{58}$ Holt 2006, p 22; See also Dietschy 2013.
} 
competition) was advanced by AC Milan chairman and, importantly, media mogul Silvio Berlusconi. $^{59}$

UEFA responded to these movements and introduced modifications to the competition format of the Champions Cup. It was in the 1991-1992 season when the quarterfinal and semi-final rounds of the European Champions Cup were replaced with two groups of four teams, the winners of which went directly to the final. The competition was rebranded and renamed as the UEFA Champions League for the 1992-1993 season. ${ }^{60}$ Over the next decade the competition would undergo several transformations, the most important of which was arguably the increase in the number of participating teams, ${ }^{61}$ allowing for more matches to be played and, in turn, increasing the revenue from the broadcasting rights.

The dynamics leading to the transformation of the old European Champions Cup into the Champions League have been researched at length, normally in the context of the wider commercialisation of football. There is a consensus that two main forces were behind the changes: (i) the development of digital and satellite channels willing to broadcast more European football and (ii) the growing awareness by the top football clubs of their economic potential, which in fact led to some clubs threatening to set up a break-away European football league outside UEFA's umbrella. ${ }^{62}$

The breakaway proposals and the formation of the G-14 in the 1990s have a twofold implication. First, in economic terms these movements suggest a clear interest by top professional clubs in the commercialisation of football. In other words, the football market was clearly re-shaping, and with a bigger 'cake' available clubs (and other stakeholders) wanted a bigger slice of the profits generated by the industry. Second, in governance terms those proposals signal a clear un-ease of the clubs with the decisions of the governing bodies. It is necessary to remind that similar breakaway moves were taking place at national level, with, for example, the top 22 clubs in England forming the Premier League in 1992. Thus, clubs were yet another stakeholder that sought to reposition themselves in the governance

\footnotetext{
${ }^{59}$ Holt 2006, pp 30-31.

${ }^{60}$ Ibid., p 31.

${ }^{61}$ In the 1997-1998 season the participation in the Champions League was open for the first time to clubs other than the national league champions. Under the current format, up to the fourth team in Europe's top ranked leagues can qualify for the tournament, albeit for the preliminary round.

${ }^{62}$ In basketball, some clubs and professional leagues broke away in 1991 from the sport's main governing body (FIBA) to form the Union of European Leagues of Basketball (ULEB) and organise their own competition called the Euroleague. For some years, the Euroleague co-existed with FIBA's own European Champions Cup, both trying to attract the top teams in Europe. At present, the Euroleague has finally established itself as the top European club competition in basketball.
} 
structures of European football. In this context, the clubs were following similar dynamics to the players. Whereas the latter had to recourse to strikes, protest and legal challenges to be 'heard', the former decided to organise new breakaway national leagues and threatened with similar moves at European level, but at some point they also considered to use the EU as an alternative policy/governance venue with clear interest in certain competition policy investigations. $^{63}$

In conclusion, the historical development of European football has seen increased commercialisation that has reached a peak with the so-called post-modern (or modern) football. In this post-modern era, the de-regulation of Europe's audiovisual market is paramount to understand the blossoming of football as an industry. In turn, these factors are extremely important to understand Bosman. Indeed, it has been argued that the creation of the Premier League and the Champions League and, finally, Bosman cannot be seen in isolation, but rather as incremental stages of the same process.

Having analysed both the context of the players market and the wider economic development of football, the chapter moves now to discuss the political and legal environment in which Jean Marc Bosman challenged the international transfer system.

\section{The political context and the ability of Luc Misson}

This section tackles a final dimension to round up our analysis of the context in which Bosman came about. Here we focus on two main elements. First, the political context at European level, and especially the increasing hostility towards football governing bodies in Brussels. Second, the section dedicates some attention to the importance of Jean Marc Bosman's legal team, led by Luc Misson and assisted by Jean-Louis Dupont. Although FIFPro had been contemplating for some time mounting a legal challenge against the international transfer system, Jean Marc Bosman's decision to frame his case in relation to freedom of movement of workers cannot be understood without reference to both Misson and Dupont. Although the latter has perhaps reaped the 'benefits' of popularity since 1995, it was the former's militant interest in the expansion of freedom of movement rights that most impacted their approach to the case.

\subsection{Increased hostility in Brussels}

\footnotetext{
${ }^{63}$ For a good summary of these dynamics involving EU institutions, clubs, players and governing bodies reshaping the governance of European football see García 2007 or García and Meier 2012; see also Geeraert et al. 2013.
} 
This chapter has already analysed how the European Commission's mild reaction to the CJEU ruling in Donà helps to explain the lack of reform in the international transfer system for a long time. And, as such, it was a contributing factor to Jean Marc Bosman's decision to go to court. However, that cautious approach to the governance and regulation of football steadily changed in Brussels during the late 1980s and early 1990s. The rather hostile position of the European Parliament towards UEFA during those years is of particular interest. Whereas it is not possible to find formal links between the hostility of EU institutions towards UEFA and the ruling of the Court in Bosman, this again should be seen as yet another contextual element to consider that Jean Marc Bosman was indeed not alone when going to court; and that the judgment was perhaps less a surprise than many wanted to believe.

The European Parliament addressed the issue of footballers' employment conditions in 1989 when it adopted a report on the freedom of movement of professional footballers drafted by the Dutch Christian Democrat James Janssen van Raay. ${ }^{64}$ Van Raay was elected to the European Parliament in the first elections in 1979 and he was a Member for 20 years, stepping down in 1999 after completing his fourth term in the Parliament. More importantly, Van Raay was one of FIFPro's founding fathers in 1965. He had a long history of involvement in players' unions as chairman of the Dutch footballers association and FIFPro. ${ }^{65}$

The Van Raay report was extremely hard on football's employment regime. It considered the transfer system 'a latter-day version of the slavery trade' ${ }^{66}$ The EP also criticised strongly nationality quotas as being contrary to the provisions of the EC Treaty. ${ }^{67}$ The report requested the Commission to start legal proceedings against UEFA, national FAs and/or individual clubs with the aim of abolishing the transfer fee system and nationality quotas. ${ }^{68}$

Thus, six years before the ruling, but just a few months before Bosman started his legal challenge, the European Parliament adopted a resolution questioning the legality of the international transfer system and nationality quotas under EU law. Given Van Raay’s affiliation as FIFPro Chairman, his report does not only indicate the interest of the Parliament

\footnotetext{
${ }^{64}$ European Parliament (1989) Resolution of the European Parliament on the Freedom of Movement of Professional Football Players in the Community, OJ C120.

${ }^{65}$ Lanfranchi and Taylor 2001, p 221.

${ }^{66}$ Supra 64, para 1.

${ }^{67}$ Ibid., para. 4 et seq.

${ }^{68}$ Ibid., para 16.
} 
in that matter. It also suggests an increase in the political awareness of players' unions to the point of using the supranational level (i.e. the European Parliament). ${ }^{69}$

The Van Raay report had an effect on other EU institutions. The European Commission decided to threaten UEFA with heavy fines should the restrictions to free movement remain in place. ${ }^{70}$ It was at that point, after protracted negotiations with Commission Vice-President Martin Bangemann that UEFA came up with the so-called 3+2 formula to progressively lift nationality quotas in European football. ${ }^{71}$

For the Commission this was just a provisionally bona-fide scheme to give football authorities some time to put their structures in line with EU law before moving towards the progressive abolition of nationality quotas. ${ }^{72}$ The European Parliament, on the other hand, criticised the agreement, considering it an unacceptable concession by the Commission to football authorities. ${ }^{73}$

It should be clear by now that the closer one gets to December 1995 the easier it is to find clear elements in support of a liberalisation of footballers' employment conditions. The political context analysed here added yet another layer of pressure to football's governance system. The traditional (and rather stable) pyramid of European football, with players' employment conditions at the very bottom, was under threat from many angles: the commercial interest of television operators, the economic desires of clubs, the political questions of EU institutions, and, of course, the demands of the players. In this context Bosman was just the straw that broke the camel's back. Considering the multitude of economic, social and structural changes that European football was undergoing in the late 1980s and early 1990s, the icing on the cake to get to Bosman was the knowledge and the intellectual curiosity of Jean Marc Bosman’s legal team.

\subsection{The importance of the legal team behind Jean-Marc Bosman}

\footnotetext{
${ }^{69}$ García and Meier 2012.

${ }^{70}$ McArdle 2000, p 38; Greenfield and Osborn 2001, p 85.

${ }^{71}$ The 3+2 formula was agreed between the Commission and UEFA on 18 April 1991; See UEFA, Agenda for the 8th UEFA conference for presidents and general secretaries of member associations (Montreux, 20 September 1991) and UEFA (1992) Report of the Secretary General for the years 1990 and 1991. ). The 3+2 formula was to be applied first in the top-divisions of professional football, being extended to the rest of nonamateur football by the end of the 1996-97 season.

${ }^{72}$ L’UEFA veut-elle la guerre? (La Dernière Heure, 19 January 1996); La UE tomará los cuartos de final como prueba en la sentencia Bosman (El País, 19 January 1996)..

${ }^{73}$ European Parliament (1994) The European Community and sport. Committee on Culture, Youth and the Media. A3-0326/94. .
} 
The history of the Bosman case is well known. Jean-Marc Bosman saw his transfer from RC Liège to US Dunkerque collapse at the end of his contract with the former. In his situation, Bosman decided to take legal action against RC Liège and the Belgian FA. When looking for legal advice, Bosman decided not to go to his parents' lawyer, but rather to a certain JeanLouis Dupont, whose girlfriend at that time was a long-term friend of Bosman. Crucially, Dupont was a young graduate in European law employed by Liège-based lawyer Luc Misson, who had already some experience in cases regarding freedom of movement. Luc Misson is a well-respected Belgian lawyer, specialised in European law. In a personal research interview with this author, Luc Misson did not hide his federalist and pro-European views, which he very much identifies with the period of the Delors Commission. ${ }^{74}$ In the early 1980 s, well before getting to know Jean MarcBosman, Luc Misson wrote some academic articles on the employment regulations of football players and the freedom of movement provisions in the Treaty. ${ }^{75}$ Dupont himself had studied for some time the regulations of sports governing bodies and their conflicts with EU law, as he had a particular academic and intellectual interest on the topic during his studies. He was convinced that sport should be brought in line with EU law. ${ }^{76}$

Another element that should not be underestimated is the fact that in the 1980s and 1990s the CJEU was clearly in the mood to widen the interpretation and scope of the Treaty's fundamental freedoms. In this respect, the knowledge and ability of Luc Misson was paramount for the outcome of the Bosman case. It was also important for the design of the legal strategy that brought up the demand for a preliminary ruling in the proceedings between Bosman and his club, the Belgian FA and UEFA. As Misson explained to the author of this chapter, he considers himself a specialist in freedom of movement because, before Bosman, he was involved in several cases in that area. In those cases the Court found in favour of the 'workers' and decided to extend the definition of 'worker' (and consequently the provisions on freedom of movement) to new social groups. ${ }^{77}$

Thus, Bosman's lawyers were of the opinion, from the start, that the only way to deal with the case was to go the European route. The player himself felt so badly treated by his club and the Belgian FA that he was extremely angry, so he wanted 'to make the transfer system

\footnotetext{
${ }^{74}$ Interview with Luc Misson (Liège, 6 June 2006).

75 Ibid.

${ }^{76}$ For more on Jean-Louis Dupont's background and agenda, see Bent et al. 2000, pp 9-22.

${ }^{77}$ Supra n 74, Interview Misson.
} 
explode if possible'. ${ }^{78}$ In that situation, both Misson and Dupont agreed that the only way ahead was to challenge FIFA and UEFA regulations on transfers and nationality quotas before the CJEU. In a way, the Bosman case was the result of the personal situation of a football player, combined with the desire of a legal team to explore the boundaries of the right to free movement, and the links between EU law and sport. It is quite curious that most people tend to associate only the name of Jean-Louis Dupont to the Bosman ruling, as he has built a prestigious career in the field of sports law. However, one cannot understand the legal approach to the case without the background, expertise, political and intellectual interests of Luc Misson, one of the forgotten names of the Bosman case that this chapter wants to remember 20 years later.

\section{Conclusion}

This chapter has proposed a challenge: to analyse Bosman without referring to the facts or the legal grounds of the case. We have argued that Bosman needs to be understood as yet another stage of the process of transformation of European football. Bosman was not the starting point of what has been labelled by some as modern football. It was only an accelerator, if at all. As explained in this chapter, Jean Marc Bosman was by no means alone. Professional football players throughout Europe had already challenged their employment conditions twenty years before him. England, France and Spain had modified their transfer systems years before Bosman. Similarly, the EU institutions increasingly questioned the international transfer system in the late 1980s and early 1990s. The political climate in Brussels was very hostile towards UEFA. It was reaching a tipping point by the time Bosman's case reached the European court. Also, professional clubs and leagues questioned the existing competition structures as they wanted a bigger share of European football's profits.

The common thread joining these dots is the commercial development of European football linked to the de-regulation of the audiovisual market in the continent. The interest of television operators to pay large sums of money to obtain football broadcasting rights put in motion a transformation in which Bosman is a stage, but not the origin. Finally, the persons that recognised these dynamics and managed to skilfully interpret the importance of European law in this context were Luc Misson and Jean-Louis Dupont.

\footnotetext{
${ }^{78}$ Ibid.
} 
The narrative has perhaps overemphasized the importance of the context leading up to Bosman. Here we may have been provocative in presenting the case as almost unavoidable. But this change of narrative looks to spur the informed debate on the $20^{\text {th }}$ anniversary of the ruling: Can we understand Bosman somehow differently and from a different disciplinary framework?

We believe that the basis of the argument is correct though. It has been argued, especially from within UEFA, that Jean-Marc Bosman could have withdrawn his case, in a similar way to what happen years later in the Oulmers-Charleroi case. One would never know whether UEFA and FIFA would have reformed the players market without a ruling of the CJEU. It is safe to affirm, though, that the structures of European football were clearly reaching a point of no return. One way or another structures and regulations had to change to adapt to the economic, political and legal pressures of the different stakeholders

\section{References}

Bent I et al. (2000) Football Confidential. BBC Worldwide limited, London

Dietschy P (2013) Making football global? FIFA, Europe, and the non-European football world, 1912-74. Journal of Global History 8:279-298.

García B (2007) UEFA and the European Union, from confrontation to co-operation? Journal of Contemporary European Research 2:3:202-223

García B and Meier H E (2012) Limits of interest empowerment in the European Union: The case of football. Journal of European Integration 34:4:359-378

García B et al. (2011) Spain: Parochialism or innovation? In: Niemann A et al. (ed) The transformation of European football: Towards the europeanisation of the national game, Manchester University Press, Manchester, pp 134-151 
Geeraert A et al. (2013) The governance network of European football: introducing new governance approaches to steer football at the EU level. International Journal of Sport Policy and Politics 5:1:113-132

Giulianotti R (1999) Football, a sociology of the global game. Polity Press, Cambridge

Greenfield S and Osborn G (2001) Regulating football: Commodification, consumption and the law. Pluto Press, London

Holt M (2006) UEFA, governance and the control of club competition in European football. Football Governance Research Centre, Birkbeck University.

Holt M (2007) The ownership and control of elite club competition in European football. Soccer and Society 8:1:50-67

Johansson, L. (1995) This Ruling Is Nothing Short of a Disaster. The European, 21 December 1995.

King A (2003) The European ritual, football in the new Europe. Ashgate, Aldershot

Lanfranchi P and Taylor M (2001) Moving with the ball, the migration of professional footballers. Berg, Oxford

Marples M (1954) A history of football. Secker \& Warburg, London

McArdle D (2000) From boot money to Bosman: Football, society and the law. Cavendish, London

Murray B (1994) Football, a History of the World Game. Scholar Press, Aldershot

Niemann A et al. (2011) The transformation of European football: Towards the europeanisation of the national game. Manchester University Press, Manchester

Parrish R (2003) Sports law and policy in the European Union. Manchester University Press, Manchester

Platts C and Smith A (2010) Money, money, money? The development of financial inequalities in English professional football. Soccer \& Society 11:5:643-658.

Roderick M (2006) The work of professional football, a labour of love? Routledge, Oxon 
Tomlinson A (1983) Tuck up tight lads: Structures of control within football culture. In: Tomlinson A (ed) Explorations in football culture, Leisure Studies Association Publications, Eastbourne, pp 165-186

Webber D (2014) No longer the people's game: Karl Polanyi and the double movement 'Against Modern Football'. free/Working\%20Papers/Webber\%20No\%20Longer\%20the\%20Peoples\%20Game\%20Karl \%20Polanyi\%20and\%20the\%20Double\%20Movement\%20Against\%20Modern\%20Football. pdf. Accessed 22 July 2015 